\title{
Model Kompetensi Komunikasi Bisnis Lintas Budaya Indonesia dan Jerman
}

\author{
Merlyn Marantika Bamanty ${ }^{1}$, Puji Lestari ${ }^{2}$, Dewi Novianti ${ }^{3}$ \\ 1,2,3Program Studi Ilmu Komunikasi, Fakultas Ilmu Sosial dan Ilmu Politik, \\ Universitas Pembangunan Nasional "Veteran" Yogyakarta \\ 1,2,3 Jalan Babarsari 2, Tambakbayan, Yogyakarta 55281, Indonesia \\ Email: bamantymerlyn@gmail.com ${ }^{1}$; puji.lestari@upnyk.ac.id ${ }^{2 *}$; dewinoviantiupn916@.gmail.com ${ }^{3}$ \\ * corresponding author
}

\begin{abstract}
Kabul Art Gallery is a company that offers batik paintings in Yogyakarta. The majority of customers are foreigners from several countries including Germany. The purpose of this study is to find a competences model in cross-cultural business communication, especially between Indonesian sellers and German buyers. This study uses descriptive qualitative methods with interviews, documentation, library research, and observation as data collection methods. This research is based on Spitzberg's cross-cultural communication competences theory, which embraces motivation, knowledge, and skills. The results of this study found a cross-cultural business communication competency model Kabul Art Gallery in the form of the motivation of the seller of the painting, the knowledge of paintings and foreign languages, as well as the ability to bargain with foreign languages that are often won by Indonesian sellers. Successful cross-cultural business communication brings benefits in developing business in a global scope. The contribution of this research is in the form of a cross-cultural communication competences model that can be applied to other companies. Keywords: Model of communication competition, Cross-curtural business communication, Communication of Indonesia Germany
\end{abstract}

\begin{abstract}
Abstrak
Kabul Art Gallery adalah perusahaan yang menawarkan lukisan batik di Yogyakarta. Mayoritas pelanggan adalah orang asing dari sejumlah negara termasuk Jerman. Tujuan penelitian ini untuk menemukan model kompetensi komunikasi bisnis lintas budaya, khususnya antara penjual Indonesia dan pembeli Jerman. Penelitian ini menggunakan metode deskriptif kualitatif dengan wawancara, dokumentasi, penelitian kepustakaan, dan observasi sebagai metode pengumpulan data. Penelitian ini didasarkan pada teori kompetensi komunikasi lintas budaya Spitzberg, yang menganut motivasi, pengetahuan, dan keterampilan. Hasil penelitian ini menemukan model kompetensi komunikasi bisnis lintas budaya Kabul Art Gallery berupa adanya motivasi penjual lukisan, adanya pengetahuan berupa lukisan dan bahasa asing, serta kemampuan dalam tawar menawar dengan bahasa asing yang kerap dimenangkan oleh penjual Indonesia. Komunikasi bisnis lintas budaya yang berhasil melahirkan manfaat dalam mengembangkan usaha dalam ruang lingkup global. Kontribusi penelitian ini berupa model kompetensi komunikasi lintas budaya yang dapat diterapkan pada perusahaan lain.
\end{abstract}

Kata kunci: Model kompetisi komunikasi, komunikasi bisnis lintas budaya, Komunikasi Indonesia Jerman

\section{Pendahuluan}

Diera digital, kemajuan teknologikomunikasi dan transportasi telah memungkinkan manusia di berbagai penjuru dunia saling mengenal dan berinteraksi dengan erat hanya melalui ponsel (Setiawan, 2018). Dewasa ini budaya asing telah menjadi bagian penting bagi penduduk di suatu negara. Komunikasi yang efektif harus dilakukan untuk menjalin kerjasama dengan pihak lain, seperti mitra bisnis, sejawat, atau orang manapun yang dapat memberikan keuntungan. Keberhasilan diplomat, pengusaha, pegawai, pekerja sosial, mahasiswa di negara lain ditentukan oleh kompetensi dalam mengatasi masalah-masalah budaya. Tanpa pemahaman antarbudaya atau lintas budaya, seseorang yang tinggal di lingkungan budaya lain hanya mengalami frustasi dan bahkan mengalami kegagalan dalam pekerjaan. Hal ini serupa dengan penelitian Musannaa (2012) yang menyatakan bahwa kearifan lokal mengandung nilai-nilai potensial yang diperlukan untuk mewujudkan pendidikan yang lebih bermakna dan relevan dalam situasi lintas budaya. Proses kearifan lokal 
yang diperlukan dalam komunikasi lintas budaya guru harus ada, agar guru dapat memberikan perhatian yang seimbang. Pebisnis yang tidak hanya menjual produknya dalam lingkup lokal atau nasional, namun pasarnya lebih luas yaitu internasional. Ketika pasarnya memasuki negara lain, maka mempelajari bahasa yang dimiliki oleh negara tersebut menjadi penting. Setidaknya mampu menguasai bahasa internasional yaitu bahasa Inggris meskipun negara yang samasama berbahasa Inggris juga belum tentu saling memahami. Kendala bahasa dapat terjadi di antara dua negara yang berbahasa sama.

Seorang pebisnis yang melakukan pekerjaannya di era digital harus dapat menyelesaikan kesulitan-kesulitan untuk memahami etika komunikasi dengan lawan bisnis. Bangsa-bangsa berlainan mendefinisikan konsep-konsep kebenaran, tanggung jawab, rasionalitas, objektivitas, kesopanan, penghinaan, kebebasan atau kebohongan secara berlainan pula. Budaya-budaya bisnis yang berbeda menyarankan etika berbicara dan etika perilaku nonverbal yang berbeda. Contohnya, berbohong untuk menjaga harmoni hubungan sosial lebih dapat diterima dalam budaya timur daripada keterusterangan dalam budaya barat yang akan menyinggung perasaan. Dengan kata lain, apa yang dianggap kebohongan dalam budaya Barat mungkin dianggap sopan santun dalam budaya Timur (Mulyana, 2015:5).

Komunikasi antarbudaya memiliki kerumitan etika bahasa verbal. Kesulitan bisa muncul saat pertama kali bertemu dengan calon mitra bisnis Salleh (2008). Bagaimana cara menyapanya, menggunakan gelarnya untuk menghormatinya atau memanggil nama pertama supaya cepat akrab. Orang Indonesia sering menyamaratakan budaya Amerika dengan orang barat lainnya. Berbeda dengan negara Jerman, hal itu dianggap kasar karena yang mempunyai gelar dipanggil berdasarkan jabatan yang dimiliki (Mulyana, 2015:7). Salah satu contoh dari kasus di atas adalah seorang profesor Jerman haruslah dipanggil dengan sebutan "Profesor" bukan "Bapak", Profesor Matinger bukan Bapak Matinger. Sebagaimana dalam konteks bisnis selain bahasa verbal, adapula kerumitan etika dalam bahasa nonverbal, misalnya ketika orang Jerman mengetukkan jarinya di atas meja artinya sebuah penghargaan atas penampilan atau pertunjukan yang ditunjukan, sedangkan di Indonesia memberikan penghargaan dengan cara applause atau tepuk tangan. Hal ini menjadi bagian dari etika komunikasi yang harus dipenuhi dalam proses komunikasi bisnis khususnya dalam lintas budaya. Cara berbicara di luar kata-kata yang kita ucapkan, seperti volume suara, intonasi, nada suara, dan sebagainya juga mengandung makna tertentu. Penggunaan ruang dan waktu perlu diperhatikan. Tanpa memahami konsep waktu budaya calon mitra bisnis, seorang pebisnis yang datang ke suatu negara asing mengalami kegagalan bisnisnya. Jadi, dalam negosiasi antarbudaya, proses komunikasi yang terjadi jelas lebih rumit daripada dalam negosiasi dengan orang-orang yang berbudaya sama (Mulyana, 2015: 6-10). Hal ini serupa dengan penelitian yang dilakukan Silintowe dan Pramudita (2017) yang menyatakan bahwa proses komunikasi bisnis lintasbudaya melibatkan persepsi, interpretasi, dan evaluasi perilaku seseorang, serta mengacu pada low context culture dan high context culture. Ketiga hal tersebut tergantung pada budaya seseorang yang nantinya menentukan makna yang melekat. Penelitian tersebut fokus pada Alila Hotel Solo, penelitian ini membahas mengenai model komunikasi bisnis lintas budaya di Kabul Art Gallery. Penelitian lain yang membahas mengenai komunikasi bisnis lintas budaya dilakukan oleh Lestari, Hendariningrum, dan Prayudi (2011). Hasil penelitian tersebut menyatakan bahwa pengusaha perak Jawa dan Padang saling berkomunikasi dengan melibatkan budaya (nilai-nilai budaya), sosiobudaya (pengalaman antaretnik), dan psikobudaya (prasangka sosial). 
Model kompetensi komunikasi antarbudaya Spitzberg yang meliputi; motivasi, pengetahuan, dan keahlian berkomunikasi, telah teruji untuk kasus di Indonesia, khususnya pengusaha perak etnik Jawa dan Padang. Penelitian ini berfokus pada komunikasi bisnis yang terjadi di mengenai model komunikasi bisnis lintas budaya antara Indonesia dan Jerman. Penelitian yang dilakukan Nugroho, Lestari, dan Wiendijarti (2012) mengenai pola komunikasi antarbudaya Batak dan Jawa di Yogyakarta. Hasil penelitian tersebut menyatakan bahwa pola budaya suku Batak di UPN "Veteran" Yogyakarta dan masyarakat asli Yogyakarta berbeda. Mahasiswa suku Batak di UPN "Veteran" Yogyakarta memiliki pola budaya low context dan masculinity, sedangkan masyarakat asli Yogyakarta memiliki pola budaya high context dan femininity. Pola komunikasi yang terjalin telah memasuki tahap komunikasi antarbudaya yang dinamis, karena telah melalui tahap interaktif dan transaksional. Masalah komunikasi antarbudaya yang terjadi yaitu, dalam penggunaan bahasa, persepsi, bentuk-bentuk komunikasi non-verbal, makanan, dan interaksi sosial, tetapi keduanya mampu memaknai dan memahami bentuk kebudayaan yang berbeda. Mahasiswa Batak yang menjadi pendatang mau mempelajari, memahami, dan menyesuaikan diri dengan karakteristik serta bentuk-bentuk komunikasi yang ada di masyarakat Yogyakarta. Penelitian ini fokus pada komunikasi binsis lintasbudaya yang terjalin antara Indonesia dan Jerman.

Menurut Spitzberg dan Cupach (Lestari, 2007), kompetensi komunikasi bisnis antarbudaya adalah kemampuan dalam berperilaku komunikasi bisnis dengan tepat dan efektif dalam suatu hubungan, baik secara verbal maupun non-verbal. Komunikasi dikatakan tepat apabila sesuai dengan harapan dalam hubungan tersebut. Dikatakan efektif bila bisa mencapai tujuan komunikasinya. Kompetensi komunikasi antarbudaya meliputi tiga hal yaitu motivasi, pengetahuan, dan keahlian komunikasi (Lestari, 2007). Seseorang atau pebisnis memahami dan mengetahui cara-cara berkomunikasi bisnis yang baik dan efektif dengan lawan bisnisnya yang berbeda budaya, misalnya segi bahasa, budaya, karakter, maka membuat bisnisnya berjalan lancar. Setelah pebisnis mengetahui pengetahuan yang luas, motivasi akan muncul. Motivasi adalah potensial kekuatan yang ada dalam diri dan dapat dikembangkan sendiri yang dapat memengaruhi hasil kinerja dalam bisnis (Sriwidodo dan Haryanto, 2010). Kemudian yang terakhir adalah keahlian, yaitu kemampuan untuk mengetahui informasi tentang budaya partner bisnisnya. Menganalisis dan memproses informasi tersebut menjadi perilaku komunikasi bisnis anatarbudaya yang layak atau tepat. Dengan kata lain, mitra bisnis dapat mengetahui apa yang ingin dikatakan dan dapat mengatakannya secara benar kepada mitra bisnis lainnya yang memiliki budaya yang berbeda

Kabul Art Gallery Yogyakarta adalah perusahaan yang bergerak di bidang seni, yaitu lukisan batik. Perusahaan tersebut berdiri sejak tahun 1980. Kabul Art Gallery Yogyakarta yang sudah berkembang selama 37 tahun mempunyai sebuah struktur yang sistematik dalam pengoperasian perusahaannya. Struktur tersebut menjadi sebuah pola komunikasi berbisnis. Ketika perusahaan sudah mengetahui pola yang dapat menaikkan perekonomian, maka pola itu tetap dipertahankan agar berjalan meningkat secara statis.

Hasil wawancara pada 13 Oktober 2016 bersama pemilik Kabul Art Gallery Yogyakarta bernama Kabul sering di panggil dengan sebutan maestro. Kabul yang berasal dari kota Klaten, terlahir dari keluarga di kampung yang memproduksi batik. Kabul belajar bagaimana cara membatik dari keluarga dan tetangganya. Ketika orang tua tidak mampu untuk membiayai kuliah dan memilih untuk berprofesi sebagai tukang becak yang berkeliling di kawasan Malioboro dari sore hingga malam. Kemampuan 
melukis Kabul sudah terlihat sejak umur 11 tahun. Kabul pun memberanikan diri menawarkan hasil lukisan pada pelanggan becaknya. Sejak itu beliau mulai dikenal oleh banyak orang terutama tukang becak sejawatnya. Menabung sedikit demi sedikit akhirnya beliau dapat membeli sebuah gudang di jalan Timoho nomor 29A, Baciro, Gondokusuman, Kota Yogyakarta, Daerah Istimewa Yogyakarta. Selama 36 tahun berjalan Kabul Art Gallery Yogyakarta pernah mengalami penurunan yaitu pada saat bom Bali tahun 2002 dan 2005. Dua tahun kemudian setelah keamanan negara telah dibersihkan dari ancaman teroris, pariwisata di Indonesia mulai membaik dan berkembang. Prinsip kesuksesan dari Pak Kabul selama ini ialah jujur, pantang menyerah dan konsisten. Tak ada hari esok jika hari ini bisa dilakukan, tidak ada nanti jika sekarang bisa.

Menurut data yang diperoleh dari perusahaan KabulArtGallery, saatinirata-rata 90\% pelanggan terdiri dari warga negara asing $(30 \%$ orang Jerman) dan $10 \%$ dari Warga Negara Indonesia. Omset pun telah mencapai miliaran rupiah pertahun, maka dari itu pentingnya komunikasi serta pelayanan yang baik harus dilakukan. Hal tersebut dapat meningkatkan kepuasan pelanggan dan memperluas pangsa pasar. Uniknya tanpa melalui media internet Kabul Art Gallery Yogyakarta selalu mendapati satu bus setiap minggu. Pola komunikasi bisnis yang Kabul Art Gallery Yogyakarta ambil, ialah melalui word of mouth (mulut ke mulut) juga bermitra atau kerjasama dengan agent tour. Terbiasa dengan kehidupan yang keras, Kabul menggunakan pendekatan secara langsung pada pembeli, yaitu memberikan penawaran dan memasarkan produk dengan harga bersahabat. Pendekatan ini baik bagi bisnisnya karena mampu membuat pembeli lebih nyaman jika ingin bernegosiasi.

Sebagian wisatawan mancanegara khususnya berasal dari Jerman yang berlibur ke Indonesia datang ke Kabul Art Gallery Yogyakarta. Pegawai dan pekerja harus mampu menguasai bahasa dan budaya orang Jerman.
Faktanya tidak semua pegawai menguasai bahasa Jerman, atau setidaknya bahasa Inggris sebagai bahasa internasional. Menurut Anica Nabe (25), salah satu informan sekaligus konsumen Kabul Art Gallery Yogyakarta asal Jerman, terkadang dirinya tidak memahami bahasa yang digunakan oleh pegawai Kabul Art Gallery Yogyakarta. Aksen bicara pegawai yang kurang jelasan dalam pengucapan. Indonesia terkenal dengan penduduknya yang sangat ramah namun penuh maksud, sehingga informan merasa kurang nyaman ketika pegawai memperbolehkan melakukan apa saja di dalam tokonya. Sebagai contoh ketika ada simbol dilarang memotret, pemilik Kabul Art Gallery Yogyakarta memaksa informan untuk berfoto bersama dengan salah satu lukisan. Informan sempat mencurigai jikalau setelah foto informan harus membeli lukisan tersebut. Bagi pembeli Jerman ini sikap yang tidak konsisten. Pernyataan yang sama pula oleh Antje (51) sebagai informan lainnya. Antje dibingungkan oleh faktor bahasa, bahwa tidak memahami ketika pegawai memberitahu dimana letak toilet. Antje memahami setelah pegawai itu menjelaskan dengan bahasa non-verbal, dengan tangannyayangmenunjukkankearahtoiletberada.

Melihat kebudayaan orang Jerman yang sedikit pendiam, kaku dan displin, pegawai Kabul Art Gallery Yogyakarta harus memahami karakter tersebut. Sehingga tidak menimbulkan rasa bingung, cemas dan pikiran yang tidak konsisten pada orang Indonesia. Menurut sekretaris sekaligus tangan kanan Kabul Art Gallery Yogyakarta, Suprapti, terdapat 30\% pengunjung berasal dari Jerman dan 50\% diantaranya berbahasa Jerman. Diperlukan sales atau pegawai yang dapat menguasai bahasa Jerman, baik bahasa formal maupun non-formal termasuk slang. Faktanya ada sales yang tidak kompeten dalam berbahasa dengan benar dan tidak mengetahui banyak mengenai budaya dari negara lain khususnya negara Jerman. Walaupun mengalami kendala bahasa, Kabul Art Gallery Yogyakarta selalu mempunyai pengunjung setiap 
hari. Dapat dikatakan saat ini Kabul menjadi seorang millyader. Keunikan lainnya ialah justru 90\% pengunjung terdiri dari orang asing, sedangkan gudang dan toko ada di dalam negeri. Masalah di atas membuat penulis tertarik untuk melakukan penelitian tentang model kompetensi komunikasi bisnis lintas budaya antara penjual Indonesia dan pembeli Jerman di Kabul Art Gallery Yogyakarta. Dari latar belakang yang telah dipaparkan, tujuan penelitian ini untuk menemukan model kompetisi dalam komunikasi bisnis lintas budaya, khususnya antara penjual Indonesia dan pembeli Jerman.

Teori Spitzberg dan Willian Cupach, Kompetensi Komunikasi Antarbudaya:

Komponen Kompetensi Komunikasi Brian Spitzberg dan William Cupach (Lestari, 2007:90) menyatakan perilaku komunikasi itu tepat dan efektif dalam satu hubungan tertentu, baik secara verbal maupun nonverbal. Komunikasi dikatakan tepat apabila sesuai dengan apa yang diharapakan dalam hubungan tersebut. Dikatakan efektif apabila bisa mencapai tujuan komunikasinya (Lestari, 2007:90). Terdapat tiga komponen kompetensi komunikasi yang menurut Spitzberg dan Cupach (Wirman, Yozani, Sari, dan Yesicha, 2018), berupa: (1) motivation (reward potential, objectives and goals, \& anxiety); (2) knowledge functions (interactions, speech act, linguistic, management, homeostatic, coordinative), dan (3) skills (composure, interaction management, altercentrism, expressiveness).

Ketiga hal tersebut saling terkait satu sama lainnya dalam menentukan outcomes (sppropriateness, effectiveness) dalam context (culture, place, relations, purpose). Lebih jelas dapat dilihat pada model gambar 1 .

Kombinasi antara motivasi, pengetahuan dan keterampilan komunikasi mengarahkan seseorang untuk tampil secara meyakinkan dalam berbagai pertemuan dengan orang lain. Melihat penampilan seseorang, orang lain yang terlibat dalam komunikasi akan menilai kompetensi komunikasi orang tersebut.
Definisi dalam ketiga komponen tersebut sebagai berikut (Lestari, 2007: 90-91): (1) motivasi komunikasi bisnis antarbudaya, yaitu keinginan untuk membuat kesan yang bagus dalam berkomunikasi bisnis dengan orang yang berbeda budaya agar komunikasi berjalan secara efektif; (2) pengetahuan komunikasi bisnis antarbudaya yaitu pengetahuan seseorang pebisnis tentang cara berkomunikasi bisnis yang baik dan efektif dengan pebisnis lainnya yang berbeda budaya; dan (3) keahlian komunikasi bisnis antarbudaya yaitu kemampuan untuk mengetahui informasi tentang budaya mitra bisnisnya, dapat menganalisis dan memproses informasi tersebut menjadi perilaku komunikasi bisnis antarbudaya yang layak atau tepat. Dengan kata lain, mitra bisnis dapat mengetahui apa yang ingin dikatakan dan dapat mengatakannya secara benar kepada mitra bisnis lainnya yang memiliki budaya yang berbeda.

Dalam penjelasan model kompetensi komunikasi antarbudaya menurut Spitzberg (Lestari, 2007: 82) mengemukakan beberapa dalil, antara lain: (1) apabila motivasi meningkat, maka kompetensi komunikasi meningkat; artinya kompetensi yang dirasakan sebagian tergantung pada seberapa besar keinginan seseorang untuk membuat kesan yang baik dan berkomunikasi secara efektif. Orang mungkin lebih termotivasi jika mereka percaya diri dan melihat adanya harapan untuk memperoleh penghargaan tertentu; (2) apabila pengetahuan komunikasi meningkat, kompetensi komunikasi meningkat; selain harus termotivasi, orang juga membutuhkan pengetahuan tentang komunikasi yang efektif. Semakin orang memahami bagaimana berperilaku dalam situasi tertentu, dianggap semakin kompeten. Pengetahuan komunikasi ini diperoleh dengan mengamati apa yang dilakukan oleh orang lain, dengan bertanya bagaimana seharusnya berperilaku, dengan mengikuti studi formal, maupun dengan belajar secara trial and error; dan (3) apabila keahlian komunikasi si aktor meningkat, 


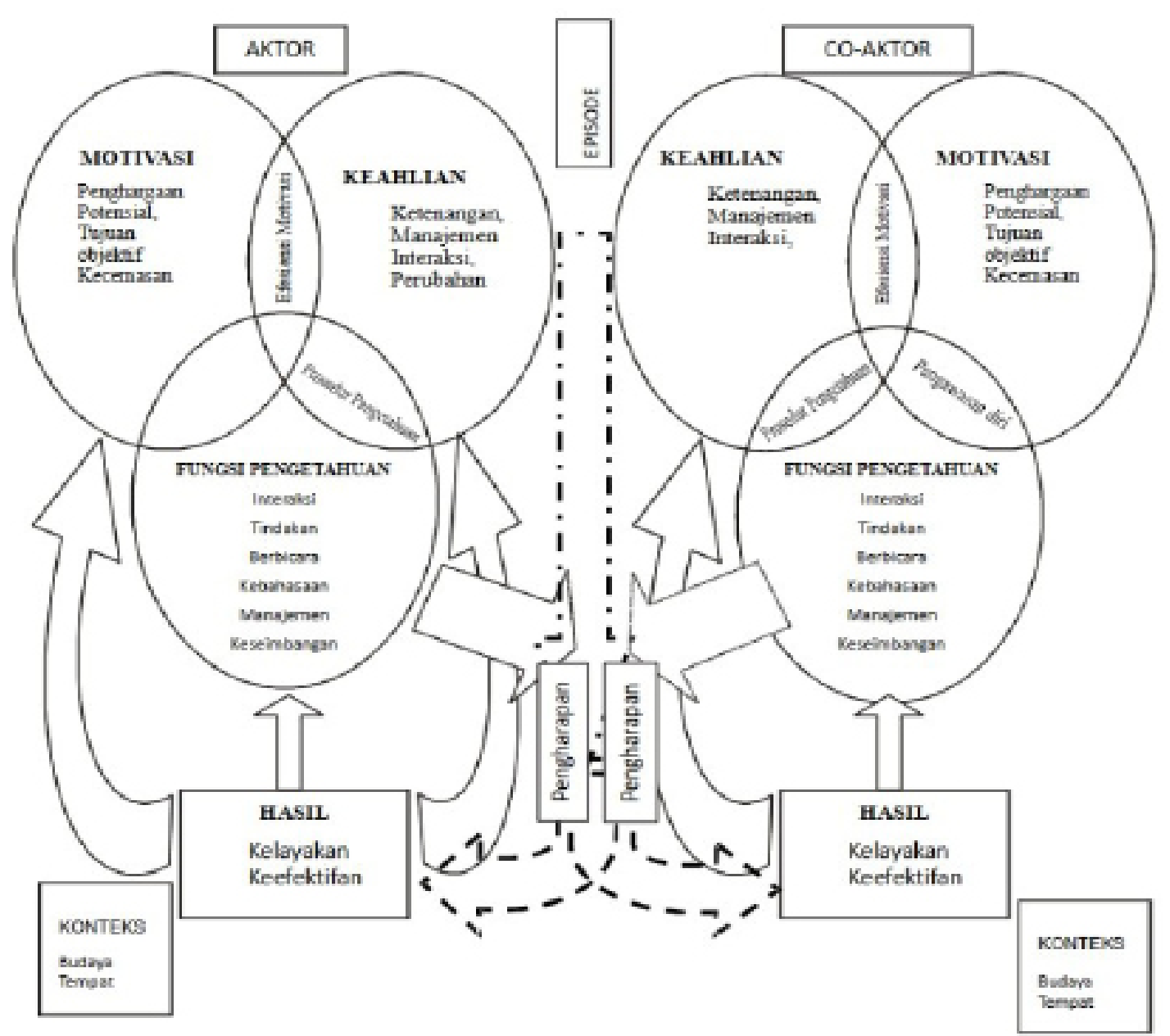

Gambar 1 Model Kompetensi Komunikasi Antarbudaya Spitzberg

Sumber: Samovar dan Porter, (2000:377); Lestari, (2007: 81)

kompetensi komunikasi aktor meningkat. Orang yang termotivasi untuk menjadi efektif dan yang mempunyai pengetahuan tentang komunikasi masih harus bertindak dengan cara yang konsisten dengan pengetahuan komunikasi mereka. Ketrampilan adalah tindakan atau serangkaian tindakan yang berorientasi pada tujuan yang bisa dikuasai dan diulang dalam situasi yang tepat. Semakin banyak ketrampilan yang dipunyai, orang semakin mampu menyusun pesan agar komunikasi tepat dan efektif.

Indikator yang digunakan untuk melihat kompetensi komunikasi bisnis antar penjual Indonesia dengan pembeli Jerman (diadaptasi dari Spitzberg dalam Samovar dan Porter, 2000:377; dalam Lestari, 2007:91-92) sebagai berikut: a) Motivasi komunikasi, diukur melalui hal-hal yang mendukung motivasi komunikasi bisnis antarbudaya yaitu: (1) adanya percaya diri dalam berkomunikasi bisnis dengan orang yang berbeda budaya, (2) harapan akan adanya imbalan yang relevan dalam berkomuniakasi bisnis dengan orang dari budaya lain, (3) adanya pendekatan kepribadian yang relevan dalam berbisnis dengan orang yang berbeda budaya, (4) Harapan adanya rasio antara biaya yang dikeluarkan dengan keuntungan yang akan diperoleh; b) Pengetahuan komunikasi bisnis antarbudaya, diukur dengan: (1) pengetahuan tentang prosedur komunikasi bisnsis dengan orang yang berbeda budaya, (2) pengetahuan tentang penguasaan strategi komunikasi bisnis 
dengan orang yang berasal dari budaya yang berbeda, (3) pengetahuan tentang identitas diri dan perbedaan peranan dalam komunikasi bisnis antarbudaya, (4) pengetahuan tentang perbedaan watak dan perilaku komunikasi bisnis dnegan orang yang berbeda budaya, (5) pengetahuan tentang relasi yang akrab dngan mitra bisnis dari budaya yang berbeda; c) Keahlian komunikasi bisnis antarbudaya, diukur dengan: (1) fokus pada orang yang diajak berkomunikasi bisnis antarbudaya, (2) koordinasi komunikasi dengan orang yang berbeda budaya, (3) ketenangan dan kepercayaan dalam berperilaku, (4) penuh perhatian dan penuh perasaan (empati), dan (5) adaptasi pembicaraan (verbal dan nonverbal).

\section{Metode Penelitian}

Jenis penelitian ini adalah deskriptif kualitatif. Lokasi penelitian di kantor Kabul Art Gallery Yogyakarta di Jalan Timoho nomor 29-A, Baciro, Gondokusuman, Kota Yogyakarta, Daerah Istimewa Yogyakarta 55165. Objek penelitian ini adalah model komunikasi kompetensi lintasbudaya. Teknik pengumpulan data dilakukan dengan (Hamidi, 2004): 1) wawancara mendalam dengan pemilik Kabul Art Gallery Yogyakarta, pihak pemasaran atau sales, dan sepuluh konsumen Kabul Art Gallery Yogyakarta yang berasal dari Jerman; 2) observasi mengenai model kompetensi komunikasi bisnis lintasbudaya antara penjual Indonesia dan pembeli Jerman di Kabul Art Gallery Yogyakarta dengan metode observasi nonpartisipan; 3) Dokumentasi berupa dokumen-dokumen menyangkut upaya yang dilakukan pendiri sekaligus pemilik Kabul Art Gallery Yogyakarta dalam menjalankan komunikasi bisnis lintasbudaya diantara penjual Indonesia dan pembeli Jerman.

Teknik analisis data dilakukan dengan (Moleong, 2011): 1) Reduksi data yang menggolongkan data dan membuang data yang tidak terkait hasil pengumpulan data dengan penelitian ini, misalnya data umur pengunjung dari Jerman; 2) Penyajian data dilakukan dengan mendeskripsikan data yang sudah direduksi, serta menyajikan dalam bentuk gambar; 3) Penarikan kesimpulan dilakukan dengan menarik inti terkait data yang sudah dikumpulkan berupa mengenai cara Kabul Art Gallery Yogyakarta dalam menyelesaikan masalah-masalah yang dihadapi oleh perusahaan, serta model komunikasi kompetensi lintasbudaya yang tercipta; dan 4) Validitas data dengan teknik trianggulasi sumber dalam menguji kevaliditasan dari data yang ada, yaitu dengan meminta pertimbangan pihak lain atas isu yang sedang diteliti.

\section{Hasil Penelitian dan Pembahasan \\ Segmentasi Pasar Kabul Art Gallery Yogyakarta}

Pembeli lukisan Kabul Art Gallery yang datang mempunyai latar belakang kepentingan: (1) bisnis: seseorang yang melakukan jual beli barang. Dalam kasus ini pebisnis ialah pembeli lukisan dari kabul Art Gallery kemudian pembeli tersebut menjual kembali. Pembeli ini akan mendapatkan harga khusus sebagai reseller. Seorang pebisnis akan memperhatikan kualitas dari lukisan yang dibelinya dan juga lukisan yang bersertifikat. Sehingga ketika pebisnis tersebut membeli lukisan yang kualitas yang bagus dan punya sertifikat asli, maka pebisnis tersebut dapat menjualnya dengan harga tinggi. Apalagi jika menjual lukisan tersebut di Eropa atau Amerika, pembeli Eropa dan Amerika akan mementingkan segi kualitas barang atau lukisan; (2) kolektor: seseorang yang mengumpulkan dana atau orang yang mengumpulkan benda untuk koleksi (prangko, benda bersejarah, lukisan dan sebagainya yang sering dikaitkan dengan minat atau hobi). Kolektor disini ialah seseorang yang mempunyai hobi untuk mengoleksi lukisan unik, antik, dan juga dengan motif yang hanya satusatunya di dunia. Kolektor berani membayar dengan harga tinggi. Bagi Kabul Art Gallery akan sangat menyenangkan jika mendapat pelanggan kolektor; (3) wisatawan: seseorang 
atau kelompok yang berwisata; pelancong dan turis. Wisatawan terdiri dari dua yaitu wisatawan mancanegara yang berasal dari luar negeri dan wisatawan domestik yang berasal dari dalam negeri. Para wisawatan yang datang ke Kabul Art Gallery mayoritas berasal dari mancanegara, terbanyaknya dari negera Belanda, Jerman, Perancis. Wisatawan mengenal Kabul Art Gallery dari agen tour and travel yang sudah bekerja sama dengan perusahaan Kabul Art Gallery. Rombongan wisatawan yang biasanya datang menggunakan bus besar ini paling disenangi oleh Bapak Kabul karena rombongan ini berpotensi untuk berhasil melakukan transaksi pembelian lukisan. Setelah transaksi selesai, lukisan yang dibawa pulang akan terpromosikan dengan sendirinya melalui word of mouth oleh para pembeli. Promosi ini menjadi media yang bagus bagi kemajuan eksistensi Kabul Art Gallery; dan (4) accidentally: arti kata accidentally dalam bahasa Indonesia adalah secara kebetulan. Kabul Art Gallery terkadang mempunyai pembeli yang secara kebetulan melewati atau sedang mencari toko lukisan Kabul Art Gallery, kemudian mengunjungi kabul Art Gallery yang terletak di kota Yogyakarta. Pembeli accidental seperti ini biasanya dibawa oleh para tukang becak dari malioboro, secara Kabul Art Gallery sudah diketahui banyak tukang becak.

\section{Elemen-elemen Komunikasi Bisnis}

\section{Pesan}

Proses komunikasi yang terjadi antara penjual dan pembeli di Kabul Art Gallery menciptakan komunikasi secara verbal dan non-verbal. Penyampaian pesan secara verbal berupa kata-kata terjadi pada saat penyampaian materi produk atau lukisan terkait mengenai keunggulan, harga produk atau lukisan, keunikan, kualitas, cara merawat, dan jumlah produk yang terbatas (hanya ada satu setiap gambar). Penjual juga menyampaikan keunggulan atas produk yang ditawarkan, bahwa lukisan yang dijual dijamin tidak akan ada yang menyamai. Setiap pembeli mendapat sertifikat keaslian atas lukisan tersebut. Diimbangi dengan proses penyampaian pesan secara non verbal, diantaranya; senyuman, kontak mata, jabat tangan, gerakan tangan, anggukan, penjual membelai atau menyentuh gambar pada lukisan, nada suara dan volume suara pembeli yang lebih keras sehingga pembeli memberikan perhatian yang dijelaskan oleh penjual mengenai produk atau lukisan.

Pada gambar 2, pesan juga disampaikan secara non-verbal melalui sebuah sign/ tanda. Tanda tersebut berarti pembeli yang datang ke Kabul Art Gallery Yogyakarta dilarang mengambil foto gambar lukisan. Tujuannya untuk menghindari adanya plagiasi karya. Penyampaian pesan dapat dikatakan efektif ketika terjadi secara langsung, proses komunikasi yang terjadi di Kabul Art Gallery berlangsung secara tatap muka. Hal ini dikarenakan ketika berkomunikasi secara tatap muka maka penjual dan pembeli akan menggunakan lisan untuk saling bertukar pikiran dan pesan, keuntungannya adalah kecepatan. Artinya penjual akan mengetahui ekspresi, tanggapan atau respon dengan segera yang diberikan oleh pembeli. Pembeli secara aktif merespon atau memberikan umpan balik dalam bentuk pertanyaan dan penyataan. Media

Kabul Art Gallery Yogyakarta masih mengunakan strategi pemasaran konvensional dalam penjualan. Kabul Art Gallery tidak

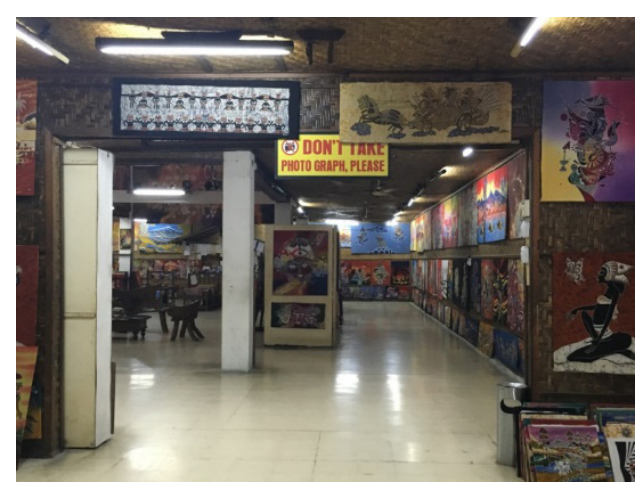

Gambar 2 Larangan memotret lukisan di dalam Kabul Art Gallery Yogyakarta

Sumber : Dokumen Penelitian, (2016) 
menggunakan jasa internet seperti website, toko online, dan lainnya melalui internet. Penjualan lukisan Kabul Art Gallery kini hanya disediakan di Kabul Art Gallery Yogyakarta, juga saat ada pameran-pameran kesenian. Media yang digunakan oleh Kabul Art Gallery yaitu media ceta. Selain media cetak Kabul Art Gallery juga menggunakan beberapa cara diantaranya: (1) brosur. Brosur adalah suatu alat untuk promosi barang, jasa dan lain-lain, yang terbuat dari kertas yang dimana di dalamnya terdapat sejumlah informasi dan juga penawaran mengenai jasa atau produk tersebut. Kabul Art Gallery memanfaatkan brosur dengan cara menyebarkan ke berbagai perusahaan agen perjalanan, dan pada pengunjung saat pameran berlangsung; (2) bermitra. Mengajak kerja sama dengan tour and travel, tukang becak di kawasan Malioboro supaya membawa pembeli ke Kabul Art Gallery Yogyakarta, mengajukan proposal kerjasama ke kedutaan Indonesia sehingga dapat bergabung di pameran kesenian Luar Negeri secara gratis; (3) word of mouth, menjaga hubungan dengan pembeli. Hal utama yang membuat perusahaannya besar ialah media pemasaran melalui mulut ke mulut (word of mouth) dari para pembeli yang puas, juga bekerja sama dengan teman-temannya yang dulu sesama tukang becak untuk membawa pelanggan mereka ke galery-nya.

Menurut Kabul media yang paling efektif ialah bermitra. Media ini dapat mendatangkan setidaknya tiga bus yang setiap bus berisi kurang lebih 30 orang. Setelah dijumlahkan minimal terdapat 90 orang yang akan datang mengunjungi Kabul Art setiap minggunya. Dari 90 orang, Kabul selalu mendapati pembeli setidaknya 10 orang.

\section{Noise atau Gangguan}

Berdasarkanhasilobservasi selama penelitian terdapat berbagai hambatan atau noise dan kendala dalam proses penyampaian pesan oleh penjual Kabul Art Gallery. Hal tersebut meliputi bahasa dan kebudayaan. Dalam segi bahasa, ketika pengunjung menanyakan letak toilet menggunakan bahasa Inggris kepada salah satu pegawai cleaning service, pegawai tersebut tidak dapat menjawab dengan bahasa Inggris. Akhirnya hanya dengan jawaban gerakan tubuh dan bantuan sales lainnya dengan bahasa yang terbata-bata.

Masalah dalam segi bahasa pun beragam. Selain kurangnya memahami bahasa lawannya, bahasa "slang" pun kerap menjadi hambatan dalam berkomunikasi. Terkadang pembeli mengunakan bahasa slang. Hal ini menjadi suatu masalah ketika penjual tidak mengerti dengan bahasa tersebut. Bahasa slang adalah bahasa yang tidak resmi dan belum baku. Biasanya anak-anak muda menggunakan bahasa ini. Bahasa slang dapat membingungkan karena multitafsir. Selain bahasa slang, pengucapan bahasa/pronounce yang tidak jelas atau clear juga menjadi noise. Pengucapan yang tidak jelas membuat pembeli bertanya berulang kali atau menanyakan kembali apa yang telah diucapkan oleh penjual.

Gangguan atau noise lainnya berasal dari sisi kebudayaan, yaitu negosiasi dan toleransi. Kebudayaan warga Indonesia selalu menolerir dan berlakunya tawar-menawar atau negosiasi dalam kehidupan sehari-hari. Terlihat dalam kehidupan sehari-hari, mulai dari yang terkecil misalnya ketika berada di pasar pembeli Indonesia akan menawar harga barang menjadi lebih murah meskipun harga sudah sangat murah. Bagi warga Eropa dengan kebudayaan langsung membeli, tawar-menawar masihlah asing, khususnya warga Jerman. Nilai-nilai warga Jerman yang lurus, disiplin, dan kaku membuat perbedaan dengan nilai-nilai di lingkungan masyarakat Indonesia. Contoh sebuah kejadian di lapangan saat ada gambar larangan memotret. Pengunjung yang berasal dari Jerman menaati peraturan. Tidak disangka pemilik Kabul Art Gallery mengijinkan bahkan menyuruh seorang pembeli Jerman untuk mengambil gambar lukisan. Kejadian ini membuat pembeli Jerman sedikit menjadi canggung dan bingung. Pembeli Jerman tersebut berpikir ketidakkonsistenan dalam membuat aturan. 
Setelahpenelitimelakukankonfirmasikepada Kabul, ternyata larangan memotret berlaku untuk foto close up secara rinci (detail) dengan kamera professional misalnya SLR. Sedangkan memotret hanya untuk mengabadikan diri sendiri di ruangan penuh lukisan tersebut menggunakan ponsel tidaklah menjadi sebuah masalah.

Penjual atau pemasaran Kabul Art Gallery memiliki beberapa kiat untuk meminimalisir hambatan-hambatan tersebut, diantaranya: (1) terus berlatih berbicara dengan orang-orang Jerman yang tinggal di Indonesia. Sering mendengarkan percakapan orang Jerman supaya paham dan fasih mengucapkan bahasa Jerman, (2) update dengan perkembangan negara Jerman atau negara lainnya supaya dapat lebih memahami kondisi pembeli Jerman atau pembeli mancanegara lainnya yang datang, dan (3) menjalin hubungan dan komunikasi yang baik dengan setiap pembeli, menyesuaikan bahasa yang digunakan dengan umur lawan bicaranya.

\section{Feedback atau respon dan dampak}

Proses interaksi dalam komunikasi yang dilakukan oleh penjual Indonesia terlihat ketika pemasaran atau sales yang langsung berhadapan (face to face) terhadap pembeli Jerman. Pihak sales menyampaikan materi produk yang meliputi harga produk, keunikan, keunggulan, kualitas, cara merawat, dan jumlah produk yang terbatas (hanya ada satu setiap gambar). Hal ini dilakukan supaya pembeli tertarik untuk membeli produk yang ditawarkan. Pemasaran atau sales juga harus menyampaikan keunggulan atas produk yang ditawarkan. Setiap pembeli mendapatkan sertifikat keaslian atas lukisan tersebut. Pembeli yang datang ke Kabul Art Gallery Yogyakarta-pun dilarang untuk mengambil foto gambar lukisan. Tujuannya untuk menghindari adanya plagiat dalam gambar lukisan. Kabul bahkan tidak ingin mengambil resiko dengan berpromosi melalui website. Interaksi yang dilakukan terkadang searah dan terkadang dua arah dengan respon yang cukup baik. Respon yang diberikan secara non-verbal

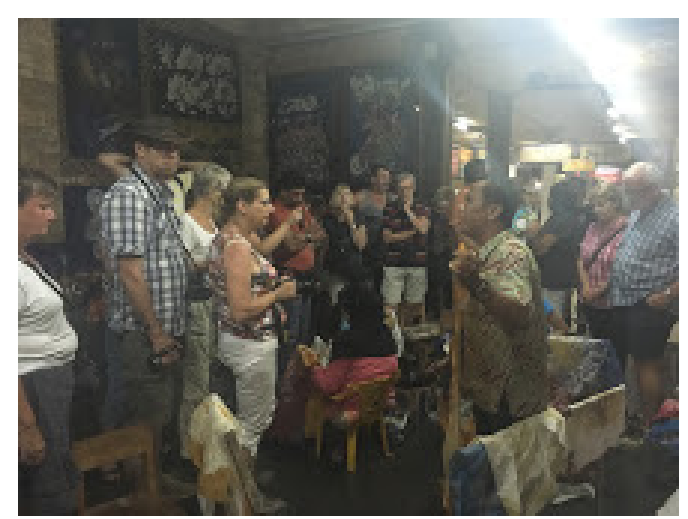

Gambar 3 (sales) yang mengenakan pakaian batik, saat menjelaskan pada pengunjung Jerman dengan bahasa Jerman.

Sumber: Dokumen Peneliti, (2016)

oleh pembeli Jerman berupa; kerutan dalam dahi yang menandakan kebingungan, senyuman mengartikan ketertarikan, mengangkat tangan karna ada yang ingin diketahui. Secara verbal, respon yang diberika pembeli Jerman ialah dengan menanyakan mengenai kualitas produk dan proses membatik atau pembuatan lukisan. Model kompetensi komunikasi bisnis Kabul Art Gallery Yogyakarta

Di dalam konteks penelitian ini, penjual harus memiliki kompetensi atau kemampuan berkomunikasi untuk mengajak pengunjung tertarik untuk membeli produk tersebut.Adapun indikasi dalam kompetensi komunikasi penjual Indonesia dan pembeli Jerman yaitu motivation, knowledge, skills, digambarkan sebagai berikut:

Perbandingan nilai-nilai budaya dan kompetensi antara penjual Indonesia dan pembeli jerman dijelaskan sebagai berikut: (1) motivation atau motivasi, adanya sebuah keinginan untuk mendapatkan penghargaan potensial, tujuan objektif, ataupun sebuah kecemasan. Menuntut dan mendorong seseorang untuk berani melakukan interaksi kepada orang lain. Penjual Indonesia terdorong memiliki kompetensi karena munculnya keinginan meraih keuntungan dari penjualan produk yang ditawarkan, target penjualan dalam sebulan, dan meraih peringkat tertinggi sehingga mendapatkan bonus. Berbagai hal 


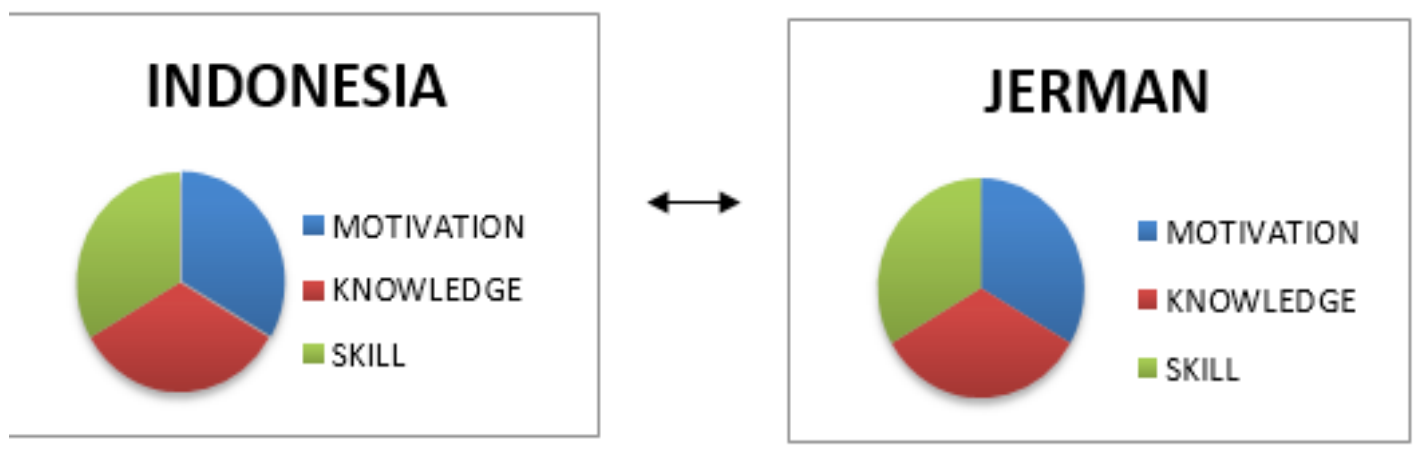

Gambar 4 Model komunikasi dua arah antara penjual Indonesia dan pembeli Jerman

Sumber: Riset lapangan, (2016)

yang membuat pembeli Jerman termotivasi untuk membeli produk yang ditawarkan, yaitu keunikan, harga murah, berkualitas, dan pride. Pembeli yang berkepentingan untuk bisnis/menjadi reseller tentu melihat dari sisi kualitas barang, pembeli yang membeli untuk sebuah oleh-oleh yang mementingkan harga yang murah, pembeli kolektor mencari sifat keunikan barang dan pembeli accidentally yang datang secara kebetulan misalnya karena melewati Kabul Art Gallery kemudian singgah untuk melihat. Pembeli Jerman yang berlibur di Indonesia tentunya menginginkan buah tangan atau handycraft khas Indonesia yaitu batik. Namun terkadang batik berupa pakaian susah untuk dikenakan di negaranya. Sehingga mereka tertarik untuk mengunjungi pabrik batik yang dapat digunakan sebagai hiasan dinding atau lukisan. Lukisan dengan teknik membatik jauh berbeda dengan lukisan yang ada dinegaranya dengan cara dilukis dengan kuas pewarna. Alasan inilah yang memotivasi pembeli untuk datang ke Kabul Art Gallery Yogyakarta; (2) knowledge atau pengetahuan, setelah termotivasi seseorang harus memiliki pengetahuan tentang lawan bicaranya. Penjual Indonesia di Kabul Art Gallery harus paham mengenai product knowledge, dari harga, kualitas barang, kuantitas, dan cara perawatannya. Tidak hanya itu, penjual Indonesia pun harus mengetahui asal lawan bicaranya, sehingga bahasa dan kebudayaannya bisa diselaraskan. Pemilik Kabul Art Gallery
Yogyakarta memberikan kursus bahasa asing tambahan untuk para pegawai pemasaran. Hal ini diberikan karena pengetahuan pegawai mengenai kebudayaan negara masing-masing pembeli tidak sepenuhnya dimengerti. Sehingga penjual harus mengikuti tata cara budaya orang barat yaitu Amerika dan Eropa sehingga pembeli dapat lebih nyaman dan tidak ada kesalahpahaman dalam bernegosiasi dan berkomunikasi. Salah satunya mempelajari tata cara budaya barat dari nilai-nilai budaya Jerman: disiplin, tepat waktu, sulit bernegosiasi maka menawarkan harga harus sewajarnya. Informasi pengetahuan yang didapatkan pembeli Jerman mengenai Indonesia yaitu tentang produk olahan batik yang berkualitas. Hal ini membuat pembeli Jerman tertarik dengan keunikan, keunggulan, dan proses produksi batik. Pembeli pun juga mengerti mengenai sifat kebudayaan Indonesia, bahwa kebudayaan Indonesia yang selalu bernegosiasi dalam segala hal, ramah, dan tentunya selalu menaikkan harga pasar ketika seorang warga negara asing membeli produk di Indonesia. Maka pembeli Jerman yang sudah mulai terbiasa dengan keadaan negara Indonesia akan mencoba menawar sedikit harga yang diberikan oleh penjual. Saat peneliti mencoba bergabung dengan penjual dan menyimak apa yang sedang dibicarakan, ternyata ada juga salah satu pembeli Jerman yang sedang berusaha bernegosiasi soal harga dengan penjual di Kabul Art Gallery Yogyakarta. 
Nampaknya negosiasi tersebut dimenangkan oleh pihak penjual Indonesia, terbukti dengan kelihaian cara berbicara dan pengaturan bahasa penjual Indonesia dapat mempertahankan harga yang ditawarkan sejak awal dan pembeli Jerman yang menyerah; (3) skills atau keahlian. Kabul Art Gallery Yogyakarta saat ini hanya menyediakan penjualan secara langsung di galery Yogyakarta dan juga pameran di berbagai negara. Sehingga memberikan kursus di sekolah bahasa pada setiap pegawainya adalah cara terbaik bisa mempromosikan lukisannya pada pembeli mancanegara. Setiap bagian sales harus menguasai setidaknya dua bahasa yaitu bahasa Inggris dan bahasa asing lainnya. Setiap sales dikursuskan dengan bahasa yang berbeda-beda, antara lain bahasa Jerman, Belanda, Mandarin, Spanyol dan Perancis. Hal ini dimaksudkan supaya pembeli dari mancanegara tidak kesulitan berkomunikasi dengan penjual Indonesia di Kabul Art Gallery Yogyakarta. Pegawai yang dapat berbahasa lebih dari satu diantaranya; Priyo (50) sebagai sales dengan spesialis bahasa Jerman dan Spanyol, Agus (41) sebagai sales dengan kemampuan bahasa Belanda dan Perancis, Tukiman (52) sebagai kepala kebersihan juga dapat menjadi bagian pemasaran dapat berbahasa Mandarin dan melayani tamu domestik. Bahasa yang pemasaran miliki cukup dimengerti lawan bicaranya. Melalui pelatihan dan pembelajaran bahasa dan budaya di tempat kursus membuat semakin hari kemampuan pegawai semakin membaik. Dari sisi keahlian pembeli Jerman, data yang diperoleh yaitu pembeli Jerman yang sudah berusia lanjut lebih kesulitan untuk berbahasa Inggris. Ini menjadi masalah dan mengganggu proses komunikasi antara pembeli dan penjual, dimana lebih banyak yang datang pembeli Jerman yang berusia lanjut sedangkan tidak semua penjual Indonesia di Kabul Art Gallery berbahasa Jerman. Keahlian bahasa menjadi hal yang penting dalam bernegosisasi. Skill berikutnya yang harus dimiliki oleh penjual dan pembeli yaitu cara bernegosiasi dengan baik.
Seorang penjual harus dapat bernegosiasi produk yang ditawarkan dengan harga tinggi, mengolah kalimat dengan halus untuk menggiring penjualnya ikut tertarik dengan keunikan dan keunggulan atas produk yang dijual. Penjual Indonesia yang telah terbiasa sehari-hari dengan kehidupan tawar-menawar atau negosisasi lebih mampu mempertahankan harga yang penjual Indonesia tawarkan. Setelah peneliti amati di lapangan, keberhasilan kemampuan tawarmenawar penjual Indonesia dengan pembeli Jerman adalah mayoritas. Keberhasilan yang diraih oleh pihak penjual Indonesia lebih besar dibandingkan pihak pembeli Jerman. Penjual Indonesia dapat memainkan harga yang ditawarkan dengan keuntungan yang tetap besar, cara yang paling berhasil ialah menaikkan harga kemudian memberikan diskon seolah-olah orang Indonesia mengikuti kemauan pembeli supaya merasa puas telah berhasil menurunkan harga, namun dibalik tawar menawar itu penjual Indonesia sudah merasa terpuaskan dengan nilai yang didapat. Skill seorang penjual harus selalu diasah untuk mendukung komunikasi lintas budaya dengan wisatawan asing, seperti halnya penelitian yang dilakukan oleh Astina dan Ketut (2016) tentang komunikasi lintas budaya antara pedagang lokal dengan wisatawan asing di Pantai Sanur. Hasil tersebut menyatakan bahwa pedagang harus memiliki karakter yang terbuka dan ramah terhadap orang asing, serta menguasai bahasa dalam bernegosiasi. Kabul Art Gallery sudah terbukti dapat bernegoisasi dengan baik ditunjukkan dalam keberhasilan memenangkan harga jual beli.

Model kompetensi komunikasi bisnis lintasbudaya antara penjual Indonesia dan pembeli Jerman di Kabul Art Gallery yang telah peneliti amati dapat disimpulkan pada gambar 5 .

Model kompetensi komunikasi bisnis lintasbudaya yang digambarkan sesuai dengan komponen kompetensi komunikasi Brian Spitzberg dan William (Adha, 2017) yang menyatakan bahwa individu yang 


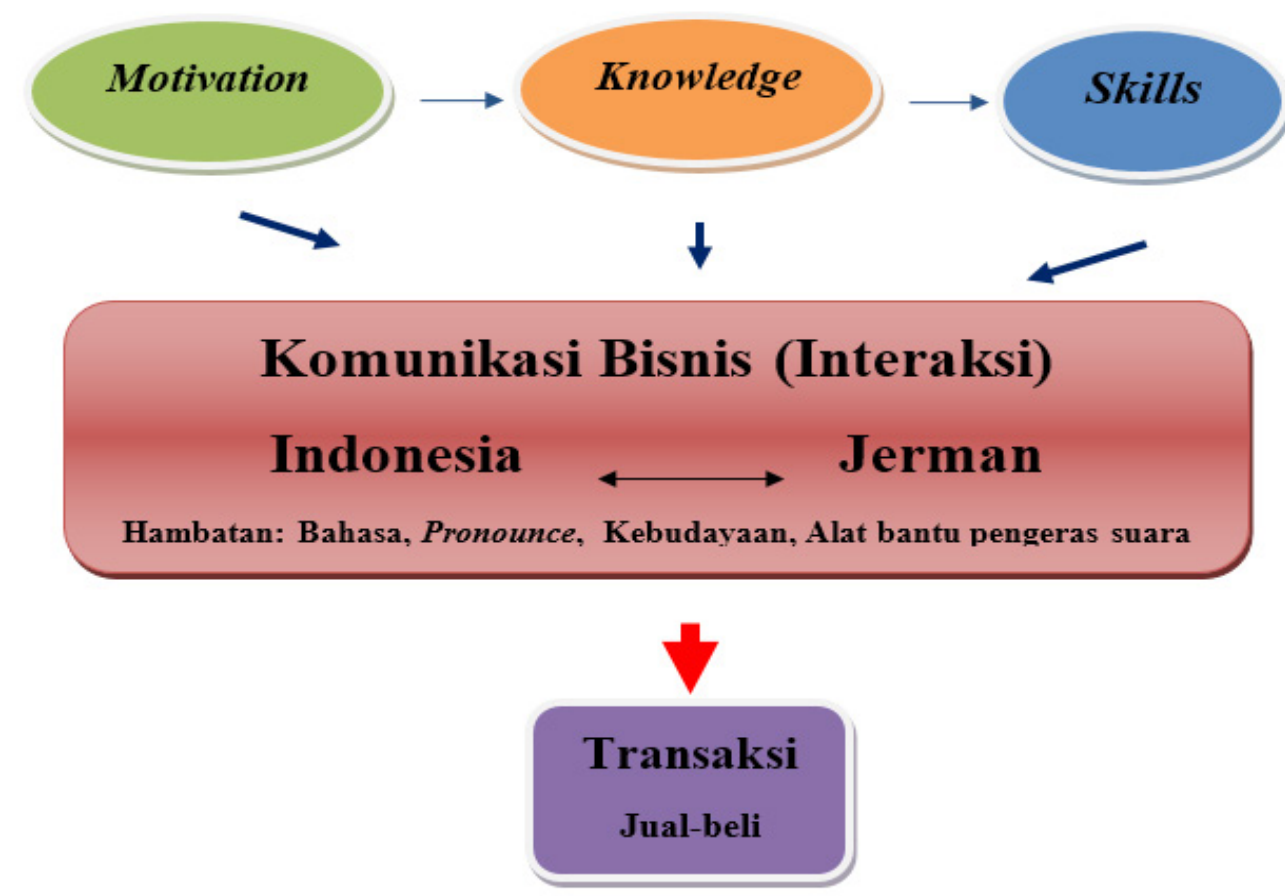

Gambar 5 Model kompetensi komunikasi bisnis lintasbudaya penjual Indonesia dan pembeli Jerman di Kabul Art Gallery

Sumber: Dokumen Peneliti, (2016)

ingin berkomunikasi secara tepat dan efektif harus memiliki motivasi, pengetahuan, dan kemampuan. Gambar 5 memiliki arti, yaitu: penjual atau pembeli harus memiliki sebuah alasan untuk termotivasi melakukan komunikasi bisnis; setelah termotivasi penjual atau pembeli harus memiliki sebuah pengetahuan tentang apa yang akan dikomunikasikan, pada siapa akan berbicara sehingga penjual atau pembeli dapat menentukan bahasa dan topik percakapan yang tepat saat berkomunikasi; motivasi dan pengetahuan harus didukung pula dengan keahlian yaitu, kemampuan dalam berbahasa jerman, kemampuan dalam bersikap ketika berhadapan dengan pembeli Jerman dan kemampuan dalam bernegosiasi nilai harga. Apabila motivation, knowledge dan skills sudah terpenuhi maka komunikasi akan berlangsung secara dua arah dengan baik. Hal ini sesuai dengan penelitian yang dilakukan oleh Luthfia (2014) mengenai pentingnya kesadaran antarbudaya dan kompetensi komunikasi antarbudaya dalam dunia kerja global. Hasil penelitian tersebut menyatakan bahwa kompetensi komunikasi antarbudaya dapat tercapai melalui proses kepekaan antarbudaya, kesadaran antarbudaya, dan ketrampilan berkomunikasi antarbudaya. Perusahaan yang memiliki kompetensi antarbudaya mampu sukses dan mempertahankan kesuksesan dalam bisnis global. Hal ini terlihat dari pemiliki Kabul Art Gallery yang dalam meningkatkan kompetensi komunikasi melalui pelatihan dan pembelajaran bahasa dan budaya di tempat kursus. Faktor-faktor yang dapat memengaruhi kemampuan dalam berbahasa adalah motivasi pekerja sebelum berinteraksi, pengetahuan komunikasi dari pekerja, kesan pekerja dan interaksi yang dilakukan (Vidyarini, 2017). Meskipun terdapat hambatan dari segi bahasa, pengucapan yang kurang jelas dan kurangnya alat bantu pengeras suara, hal itu tidak terlalu menjadi masalah bagi pembeli Jerman dan penjual Indonesia untuk saling berinteraksi. Keberhasilan dari proses komunikasi bisnis tersebut ialah dengan adanya transaksi jual beli. 


\section{Simpulan}

Penelitian ini menghasilkan model komunikasi kompetensi bisnis pada Kabul Art Gallery, yaitu menggunakan model kompetensi komunikasi bisnis lintasbudaya yang tidak berbeda dengan teori Spitzberg yaitu model kompetensi komunikasi antarbudaya. Kabul Art Gallery Yogyakarta menggunakan konsep tersebut diawali dengan rasa motivasi ingin menjual lukisan, mendapatkan keuntungan dan mendapatkan sebuah bonus. Kemudian setelah termotivasi maka penjual akan mempelajari pengetahuan mengenai latar belakang pembeli Jerman seperti bahasa yang berbeda, kebudayaan cara melayani pembeli Jerman. Kemudian setelah mempunyai knowledge maka penjual Indonesia akan mempelajari mengenai pembeli Jerman sehingga akan muncul keahlian. Melalui kursus bahasa Jerman, penjual Indonesia memiliki keahlian yang baik untuk mengawali berkomunikasi dengan pembeli jerman. Selain itu penjual Indonesia juga memiliki keahlian dalam tawar menawar dan transaksi tersebut sering kali dimenangkan oleh penjual Indonesia dalam bernegosiasi dengan pembeli Jerman. Kontribusi penelitian ini berupa model kompetisi komunikasi lintas budaya yang dapat diterapkan pada perusahaan lain.

\section{Daftar Pustaka}

Adha, S. (2017). Kompetensi Komunikasi Fasilitator Kecamatan dalam Program Nasional Pemberdayaan Masyarakat Mandiri Pedesaan di Langkat. JURNAL SIMBOLIKA: Research and Learning in Communication Study, 3(1), 55-65.https:// doi.org/10.31289/simbollika.v3i1.1218 Astina, M. A., \& Ketut, K. (2016, November). Komunikasi Lintas Budaya antara Pedagang Lokal dengan Wisatawan Asing di Pantai Sanur. In Prosiding Seminar Nasional INDOCOMPAC. Hamidi. (2004). Metode Penelitian Kualitatif. Universitas Muhammadiyah Malang, Malang.
Lestari, P. (2007). Stereotip Dan Kompetensi Komunikasi Bisnis Antarbudaya Bali Dan Cina (Studi Di Kalangan Pengusaha Perak Bali Dan Cina). Jurnal Ilmu Komunikasi, 4(1). https://doi.org/10.24002/jik.v4i1.230

Lestari, P., Hendariningrum, R., \& Prayudi, P. (2011). Kompetensi Komunikasi Bisnis Lintas Budaya. Jurnal Ilmu Komunikasi, 9(3), 250-265. Luthfia, A. (2014). Pentingnya Kesadaran Antarbudaya dan Kompetensi Komunikasi Antarbudaya dalam Dunia Kerja Global. Humaniora, 5(1), 9-22. https://doi. org/10.21512/humaniora.v5i1.2976 Moleong,LexyJ.(2011).MetodologiPenelitian Kualitatif, Remaja Rosdakarya, Bandung. Mulyana, Deddy. (2015). Komunikasi Lintas Budaya. Bandung: Remaja Rosdakarya. Musanna, A. (2012). Artikulasi Pendidikan Guru Berbasis Kearifan Lokal untuk Mempersiapkan Guru yang Memiliki Kompetensi Budaya. Jurnal Pendidikan dan Kebudayaan, 18(3), 328-341. https://doi:10.24832/jpnk.v18i3.92 Nugroho, A. B., Lestari, P., \& Wiendijarti, I. (2012). Pola komunikasi antarbudaya Batak dan Jawa di Yogyakarta. Jurnal ASPIKOM, 1(5), 403-418. $\underline{\text { http:// }}$ dx.doi.org/10.24329/aspikom.v1i5.44 Salleh, Lailawati Mohd. (2008). Communication Competence: A Malaysian Perspective. Human Communication, 11(3). 303-312. Setiawan, D. (2018). Dampak perkembangan teknologi informasi dan komunikasi terhadap budaya. JURNAL SIMBOLIKA: Research and Learning in Communication Study, 4(1), 62-72. https://doi. org/10.31289/simbollika.v4i1.1474 Silintowe, Y. B. R., \& Pramudita, M. C. C. (2017). Komunikasi bisnis lintas budaya sekretaris pada atasan (studi pada Alila Hotel Solo). Jurnal Komunikasi, 8(2), 147- 
158. https://doi.org/10.24912/jk.v8i2.67 Sriwidodo, U., \& Haryanto, A. B. (2010). Pengaruhkompetensi,motivasi,komunikasi dankesejahteraan Terhadapkinerja pegawai dinas pendidikan. Jurnal Manajemen Sumber Daya Manusia, 4(1), 47-57. Vidyarini, T. N. (2017). ADAPTASI BUDAYA OLEH MAHASISWA INTERNASIONAL: PERSPEKTIF KOMUNIKASI LINTAS BUDAYA.
Scriptura, 7(2), 71-79. https://doi. org/10.9744/scriptura.7.2.71-79 Wirman, W., Yozani, R. E., Sari, G. G., \& Yesicha, C. (2018). PELATIHAN KOMPETENSI KOMUNIKASI LINTAS BUDAYA DALAM MEMPERSIAPKAN MASYARAKAT SADAR WISATA DI KOTA SIAK SRI INDRAPURA KABUPATEN SIAK. Jurnal Ilmu Komunikasi, 8(4). 